\title{
Mouse Genetic Approaches to Investigating Calcium/ Calmodulin-Dependent Protein Kinase II Function in Plasticity and Cognition
}

\author{
Ype Elgersma, ${ }^{1}$ J. David Sweatt, ${ }^{2}$ and K. Peter Giese ${ }^{3}$ \\ ${ }^{1}$ Department of Neuroscience, Erasmus Medical Center, 3000 DR, Rotterdam, The Netherlands, ${ }^{2}$ Department of Neuroscience, Baylor College of Medicine, \\ Houston, Texas 77030, and ${ }^{3}$ Wolfson Institute for Biomedical Research, University College London, London, WC1E 6BT, United Kingdom
}

Key words: calcium; calmodulin; learning; localization; LTP; NMDA; phosphatase; protein kinase; knock-out mice; memory; mental retardation; gene targeting; transgenic mice; knock-in mice; hippocampus; Angelman's

The knock-out of $\alpha$-calcium/calmodulin-dependent protein kinase II (CaMKII) was the kickoff for a new subfield in neuroscience, in which mouse mutants are used as a tool to gain insight into the molecular basis of cognition and brain plasticity. In our review, we give an overview of the $\alpha$ CaMKII mutants that have since been developed, and we summarize the key findings that these studies have provided on the function of $\alpha$ CaMKII in hippocampal plasticity, cortical plasticity, and learning and memory. Furthermore, we discuss recent results that misregulation of $\alpha$ CaMKII function may cause the neurological symptoms in Angelman's syndrome (AS).

\section{$\alpha$ CaMKII mutants}

To investigate the physiological role of $\alpha$ CaMKII in vivo, several mutants have now been generated (Table 1). One group of mutants was designed to manipulate the level of (active) $\alpha$ CaMKII. For instance, gene targeting was used to manipulate the endogenous $\alpha$ CaMKII gene to obtain null mutants that do not express $\alpha$ CaMKII protein, as well as heterozygous null mutants that express $\sim 50 \%$ of the normal level of $\alpha$ CaMKII (Silva et al., 1992a,b; Elgersma et al., 2002). Gene targeting was also used to create hippocampal area CA3-restricted null mutants of $\alpha$ CaMKII (Hinds et al., 2003). In addition, several lines of transgenic mice have been generated to increase $\alpha$ CaMKII activity levels, such as (1) transgenic $\operatorname{Tg}(\mathrm{T} 286 \mathrm{D})$ mutants that have constitutive overexpression of mutated $\alpha$ CaMKII mimicking the autonomous activity of $\mathrm{Thr}^{286}$-autophosphorylated kinase but being resistant to phosphatase regulation (Mayford et al., 1995), (2) inducible $\mathrm{Tg}(\mathrm{T} 286 \mathrm{D})$ mutants, overexpressing the mutated $\alpha$ CaMKII protein under the control of the tet-OFF system (Mayford et al.,

Received July 16, 2004; revised Aug. 25, 2004; accepted Aug. 25, 2004.

This work was supported by the Nederlandse Organisatie voor Wetenschappelijk Onderzoek-Medische Wetenschappen (Y.E.), the National Institutes of Health (J.D.S.), and a British Medical Research Council Career Establishment Grant (K.P.G.).

Correspondence should be addressed to any of the following: J. David Sweatt, Department of Neuroscience, Baylor College of Medicine, One Baylor Plaza, Houston, TX 77030, E-mail: jsweatt@bcm.tmc.edu; Ype Elgersma, Department of Neuroscience, Erasmus Medical Center, 3000 DR, Rotterdam, The Netherlands, E-mail: y.elgersma@erasmusmc.nl; or K. Peter Giese, Wolfson Institute for Biomedical Research, University College London, WC1E 6BT, UK, E-mail: p.giese@ucl.ac.uk.

DOI:10.1523/JNEUROSCI.3622-04.2004

Copyright $\odot 2004$ Society for Neuroscience $\quad$ 0270-6474/04/248410-06\$15.00/0
1996), and (3) $\operatorname{Tg}(\mathrm{F} 89 \mathrm{G})$ mutants, overexpressing mutated $\alpha$ CaMKII protein having normal kinase activity but containing an altered structural domain allowing specific blockade by a designed inhibitor (Wang et al., 2003). The inhibitor blocks reversibly and does not inhibit endogenous $\alpha$ CaMKII.

A second group of mutants is aimed at investigating the physiological importance of $\alpha$ CaMKII autophosphorylation and of local $\alpha$ CaMKII protein synthesis. These mutants are generated by knock-in technology, resulting in a mutation of the endogenous $\alpha$ CaMKII gene. Mutants belonging to this group are (1) T286A mutants expressing $\alpha$ CaMKII that cannot be autophosphorylated at $\mathrm{Thr}^{286}$ (Giese et al., 1998), (2) T305V/T306A point mutants expressing $\alpha$ CaMKII protein that cannot be autophosphorylated at $\mathrm{Thr}^{305}$ and $\mathrm{Thr}^{306}$ (Elgersma et al., 2002), (3) T305D point mutants expressing $\alpha$ CaMKII mimicking constitutive autophosphorylation at $\mathrm{Thr}^{305}$ that blocks activation of the kinase by CaM (Elgersma et al., 2002), and (4) deletions of the dendritic localization signal within the $3^{\prime}$ untranslated region (UTR) of the $\alpha$ CaMKII mRNA that abrogate dendritic synthesis of CaMKII $\alpha$ protein and reduce dendritic CaMKII $\alpha$ protein levels (Miller et al., 2002).

\section{Hippocampal synaptic plasticity}

Induction and maintenance of long-term potentiation

The function of $\alpha$ CaMKII in synaptic plasticity has been most intensively studied at Schaffer collateral-CA1 pyramidal neuron synapses in the adult hippocampus. Analysis of the null mutants showed that the kinase is required for the induction of NMDA receptor-dependent long-term potentiation (LTP) at CA1 synapses (Silva et al., 1992a; Hinds et al., 1998; Elgersma et al., 2002). However, these studies also suggested that $\alpha$ CaMKII is not essential for CA1-LTP, because residual LTP could be obtained in the null mutants. Recent studies revealed a compensatory translocation of $\beta$ CaMKII to PSDs (postsynaptic densities) in the null mutants, which is likely to be responsible for the residual LTP (Elgersma et al., 2002). No such compensation is observed in the T305D mutants and in the T286A mutants, and, in these mutants, CA1-LTP is completely absent (Giese et al., 1998; Elgersma et al., 2002). Because all $\beta$ CaMKII subunits are associated with $\alpha$ CaMKII subunits, it is likely that these mutations in $\alpha$ CaMKII affect the function of the entire holoenzyme (Brocke et al., 1999). Although $\alpha$ CaMKII and its autophosphorylation at $\mathrm{Thr}^{286}$ are 
Table 1. Overview of CaMKII mutants and their phenotypes

\begin{tabular}{|c|c|c|c|c|}
\hline $\operatorname{Mutant}^{a}$ & Purpose & Molecular characterization ${ }^{b}$ & Plasticity $^{b}$ & Behavioral phenotype \\
\hline$\alpha$ CaMKII-null $(-/-)^{1,2}$ & Elimination of $\alpha$ CaMKII protein & $\begin{array}{l}\text { Expression level of } \beta \text { CaMKII is } \\
\text { unaltered }^{1,2} \text { but targeting of } \\
\beta C \text { aMKII to PSD is increased }{ }^{2}\end{array}$ & $\begin{array}{l}\text { HC-LTP reduced }{ }^{1-3} \\
\text { NC-LTP reduced in adult animals } \\
\text { NC-LTP normal in young animals } \\
\text { Decreased PPF } \\
\text { Normal } 1 / 0^{2}\end{array}$ & $\begin{array}{l}\text { Hippocampus-dependent learning severely } \\
\text { impaired but learning in some animals is } \\
\text { observed after extended training }{ }^{1,2,6} \\
\text { Increased seizure susceptibility }{ }^{7} \text { (background } \\
\text { dependent? }^{2} \text { ) }\end{array}$ \\
\hline$\alpha$ CaMKII-null $(+/-)^{1,2}$ & Reduction of $\alpha$ CaMKII protein & $\begin{array}{l}\alpha \text { CaMKII 50\% reduced, } \beta \text { CaMKII } \\
\text { levels normal }\end{array}$ & $\begin{array}{l}\text { HC-LTP normal }{ }^{2,8,9} \\
\text { NC-LTP reduced } \\
\text { Decreased } \text { PPF }^{8} \\
\text { Increased augmentation }\end{array}$ & $\begin{array}{l}\text { Normal learning }{ }^{2} \text { or reduced hippocampus- } \\
\text { dependent learning }{ }^{8} \text { (background and } \\
\text { protocol dependent) } \\
\text { Severely impaired remote memory }{ }^{10} \\
\text { Decreased fear and increased aggressive } \\
\text { behavior }{ }^{11}\end{array}$ \\
\hline $\begin{array}{l}\alpha \text { CaMKIl-Floxed } \\
\quad+\text { CA3-cre }^{12}\end{array}$ & $\begin{array}{l}\text { Elimination of } \alpha \text { CaMKII protein in } \\
\text { CA3 area }\end{array}$ & $\begin{array}{l}\alpha \text { CaMKIl is absent from CA3 area } \\
\text { after } 4 \text { months of age }\end{array}$ & $\begin{array}{l}\text { Increased frequency facilitation } \\
\text { Normal PPF and basal } P_{\mathrm{r}}\end{array}$ & Not tested \\
\hline$\alpha$ CaMKII-T286A ${ }^{13}$ & $\begin{array}{l}\text { Blocks T286 phosphorylation } \\
\text { (no autonomous activity) }\end{array}$ & $\begin{array}{l}\text { Normal expression level of } \\
\alpha / \beta C \text { aMKII; } \mathrm{Ca}^{2+} \text {-indepen- } \\
\text { dent activity reduced by } 60 \%\end{array}$ & $\begin{array}{l}\text { HC-LTP and NC-LTP impaired }{ }^{13-16} \\
\text { Normal } \mathrm{I} / 0^{13}\end{array}$ & $\begin{array}{l}\text { Severely impaired learning in water } \\
\qquad \text { maze }^{13,17} \\
\text { Unstable place cells }^{18}\end{array}$ \\
\hline Tg- $\alpha$ CaMKII-T286D 19 & $\begin{array}{l}\text { Mimics constitutive T286 } \\
\text { phosphorylation }\end{array}$ & $\begin{array}{l}\mathrm{Ca}^{2+} \text { independent activity two- } \\
\text { fold increased }\end{array}$ & $\begin{array}{l}\text { Favors LTD }{ }^{19} \\
\text { Normal NC-LTP20 } \\
\text { Normal PPF }\end{array}$ & $\begin{array}{l}\text { Impaired learning in Barnes maze } \\
\text { Impaired olfactory-based spatial learning } \\
\text { Normal cued and contextual conditioning } \\
\text { Unstable place cells } \\
\text { U3 }\end{array}$ \\
\hline $\begin{array}{l}\text { Tg- } \alpha \text { CaMKII-T286D } 24 \\
\text { (Tet inducible) }\end{array}$ & $\begin{array}{l}\text { Mimics constitutive T286 phosphory- } \\
\text { lation in an inducible manner }\end{array}$ & $\begin{array}{l}\mathrm{Ca}^{2+} \text {-independent activity } \\
\text { sixfold increased at maximum } \\
\text { induction }\end{array}$ & $\begin{array}{l}\text { Favors LTP at low expression level }{ }^{25} \\
\text { Favors LTD at high expression level }{ }^{24,25} \\
\text { NC-LTP and LTD normal }\end{array}$ & $\begin{array}{l}\text { Impaired learning in Barnes maze } \\
\text { Impaired learning in water maze } \\
\text { Impaired cued and contextual condition- } \\
\text { ing } \\
\text { in,25 }\end{array}$ \\
\hline$\alpha$ CaMKII-TT305/6VA ${ }^{2}$ & $\begin{array}{l}\text { Blocks T305/T306 (inhibitory) } \\
\text { phosphorylation }\end{array}$ & Increased levels of CaMKII in PSD & $\begin{array}{l}\text { Favors LTP } \\
\text { Normal LTD and I/0 }\end{array}$ & $\begin{array}{l}\text { Impaired water maze learning (initial learn- } \\
\text { ing okay) } \\
\text { Impaired reversal learning } \\
\text { Impaired context discrimination } \\
\text { Old mice get seizures }\end{array}$ \\
\hline$\alpha$ CaMKII-T305D² & $\begin{array}{l}\text { Mimics constitutive T305 (inhibitory) } \\
\text { phosphorylation }\end{array}$ & $\begin{array}{l}\text { Severely reduced levels of } \\
\qquad \alpha / \beta C \text { aMKII in PSD }\end{array}$ & $\begin{array}{l}\text { Favors LTD } \\
\text { No LTP } \\
\text { Normal LTD and I/0 }\end{array}$ & $\begin{array}{l}\text { Severely impaired in water maze and cued } \\
\text { conditioning (cannot learn after over- } \\
\text { training) }\end{array}$ \\
\hline 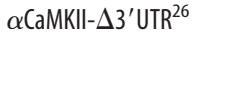 & Impairs dendritic targeting of mRNA & $\begin{array}{l}\text { Reduced amount of PSD associ- } \\
\text { ated CaMKII }\end{array}$ & $\begin{array}{l}\text { Normal (early) LTP } \\
\text { Reduced late-phase LTP }\end{array}$ & $\begin{array}{l}\text { Impaired learning in water maze } \\
\text { Normal STM but impaired LTM after cued and } \\
\text { contextual conditioning }\end{array}$ \\
\hline Tg- $\alpha$ CaMKII-F89G 27 & $\begin{array}{l}\text { Inducible system allowing rapid } \\
\qquad(8 \mathrm{~min}) \text { reversible decrease of } \\
\alpha \text { CaMKII transgene activity }\end{array}$ & $\begin{array}{l}\mathrm{Ca}^{2+} \text {-(in)dependent activity } \\
\text { twofold to threefold in- } \\
\text { creased without inhibitor }\end{array}$ & $\begin{array}{l}\text { Normal I/O and PPF } \\
\text { Enhanced LTD at } 3 \mathrm{~Hz} \\
\text { Enhanced LTP at }>10 \mathrm{~Hz}\end{array}$ & $\begin{array}{l}\text { Impaired memory consolidation of contex- } \\
\text { tual and cued conditioning when CaMKII } \\
\text { activity is changed at the first week after } \\
\text { training. }\end{array}$ \\
\hline Ube $3 A^{28,29}$ & $\begin{array}{l}\text { Encodes E6-AP ubiquitin ligase; mouse } \\
\text { model for Angelman's syndrome }\end{array}$ & $\begin{array}{l}\text { Increased T286-P and T305-P30 } \\
\text { Decreased } \alpha \text { CaMKII in PSD } \\
\text { Decreased PP1/PP2A activity }\end{array}$ & $\begin{array}{l}\text { Impaired LTP28 } \\
\text { Normal } 1 / 0^{28}\end{array}$ & $\begin{array}{l}\text { Impaired spatial learning } \\
\text { Impaired motor coordination } \\
\text { Inducible seizures } \\
\text { In,29 }\end{array}$ \\
\hline
\end{tabular}

${ }^{a}$ References given in this column refer to primary papers describing the generation and analysis of the mutant. Mutants are made by homologous recombination unless otherwise specified.

${ }^{b}$ Molecular characterization and plasticity refers to the hippocampus unless otherwise specified.

${ }^{1}$ Silva et al., 1992; ${ }^{2}$ Elgersma et al., 2002; ${ }^{3}$ Hinds et al., 1998; ${ }^{4}$ Glazewski et al., 1996; ${ }^{5}$ Kirkwood et al., 1997; ${ }^{6}$ Gordon et al., 1996; ${ }^{7}$ Butler et al., 1995; ${ }^{8}$ Silva et al., $1996 ;{ }^{9}$ Frankland et al., $2001 ;{ }^{10}$ Frankland et al., $2004 ;{ }^{11}$ Chen et al., 1994; ${ }^{12} \mathrm{Hinds}$ et al., 2003; ${ }^{13} \mathrm{Giese}$ et al., 1998; ${ }^{14} \mathrm{Glazew}$ ski et al., 2000; ${ }^{15} \mathrm{Hardingham}$ et al., 2003; ${ }^{16}$ Taha et al., 2002; ${ }^{17}$ Need et al., 2003; ${ }^{18} \mathrm{Cho}$ et al., $1998 ;{ }^{19}$ Mayford et al., 1995; ${ }^{20} \mathrm{Glazewski}$ et al., 2001; ${ }^{21}$ Bach et al., 1995; ${ }^{22}$ Wiedenmayer et al., 2000; ${ }^{23}$ Rotenberg et al., 1996; ${ }^{24}$ Mayford et al., 1996; ${ }^{25}$ Bejar et al., 2002; ${ }^{26}$ Miller et al., 2002; ${ }^{27}$ Wang et al., 2003; ${ }^{28}$ Jiang et al., $1998 ;{ }^{29}$ Miura et al., $2002 ;{ }^{30}$ Weeber et al., 2003.

NC, Neocortex; $/ / 0$, input/output (a parameter used to assess synaptic transmission); HC, hippocampus; LTM, long-term memory (24 hr); PSD, postsynaptic density; PPF, paired pulse facilitation; $P_{r}$, probability of release; STM, short-term memory (30 min); $\mathrm{Tg}$, transgenic.

essential for the induction of CA1-LTP, autophosphorylation at $\mathrm{Thr}^{286}$ is not needed for CA1-LTP during early postnatal life (Yasuda et al., 2003), which may explain the lack of morphological and developmental defects in the $\alpha$ CaMKII mutants.

$\alpha$ CaMKII is not only required for CA1-LTP induction but also plays a role in the late phase of LTP. Using mutant mice with a deletion of the $3^{\prime} \mathrm{UTR}$ in the $\alpha$ CaMKII mRNA, Miller et al. (2002) showed that these mutants are impaired in the protein synthesis-dependent phase of CA1-LTP. These data imply that late-phase LTP requires either local synthesis of new $\alpha$ CaMKII protein or some other important regulatory event abrogated by the constitutively reduced levels of dendritic $\alpha$ CaMKII protein.

\section{Metaplasticity}

$\alpha$ CaMKII appears to be a key player in the regulation of metaplasticity, which is defined as an activity-dependent change in synaptic plasticity and which controls the threshold of LTP induction to prevent saturation of synaptic plasticity (Abraham and Tate, 1997). In mice carrying the T305D mutation, which blocks activation and translocation of CaMKII to the PSD, a 10 $\mathrm{Hz}$ tetanus induces long-term depression (LTD), whereas this stimulus does not change synaptic efficacy in wild-type mice. In contrast, mice expressing $\alpha$ CaMKII, which cannot be phosphorylated at the inhibitory $\mathrm{Thr}^{305} / \mathrm{Thr}^{306}$ sites, show marked LTP for the same stimulus (Elgersma et al., 2002). Importantly, although 
T305D mice favor LTD and T305/T306VA mice favor LTP, a weak stimulus does not induce more LTD in T305D mutants, nor does a strong stimulus result in more LTP in T305/T306VA mice. This suggests that T305/T306 may be an important regulatory site in controlling the threshold of LTP induction. Furthermore, $\alpha$ CaMKII activity seems to lower the threshold of LTP induction. Consistent with this idea, a shift favoring LTP induction is observed in $\operatorname{Tg}(\mathrm{T} 286 \mathrm{D})$ mutants, overexpressing low levels of constitutively active $\alpha$ CaMKII (Bejar et al., 2002). Moreover, the amount of $\alpha$ CaMKII can affect the amplitude of synaptic efficacy. Just increasing the total amount of $\alpha$ CaMKII protein gives rise to both increased LTD after weak stimulation and increased LTP after strong stimulation (Wang et al., 2003), thus exaggerating the bidirectional effects of $\alpha$ CaMKII on plasticity without changing the threshold in any particular direction. Together, these findings indicate that the phosphorylation (activation) state of CaMKII determines the threshold of LTP induction at weaker stimulation, whereas the total amount of available CaMKII determines the amplitude of the potentiation during very strong stimulation.

Clearly, there must be limits to the extent to which the threshold for LTD-LTP induction can be manipulated because it is essential for neuronal function to keep this window in a distinct working range. Indeed, high expression of constitutively active CaMKII in $\mathrm{Tg}(\mathrm{T} 286 \mathrm{D})$ mutants shifts the threshold toward LTD rather than LTP (Mayford et al., 1995, 1996; Bejar et al., 2002). This is probably attributable to compensatory mechanisms that are recruited to deal with these high amounts of active CaMKII and that shift the threshold to the left. Currently, there is evidence for at least three such mechanisms. First, activated CaMKII expression can induce compensatory gene expression either in the neurons that express activated $\alpha$ CaMKII or other (inhibitory) neurons, such as an upregulation of the inhibitory neuropeptide $\mathrm{Y}$, which could reduce the threshold of LTP induction (Bejar et al., 2002). Second, in Drosophila, it has been shown that neurons expressing activated CaMKII can decrease their intrinsic excitability by increasing potassium currents (Park et al., 2002). In addition, recent studies showed that expression of activated $\alpha$ CaMKII results in increased surface expression of $\mathrm{K}_{\mathrm{v}} 4.2$ in cell culture, providing additional evidence that CaMKII can directly modulate intrinsic excitability (Varga et al., 2004). Third and finally, Turrigiano and colleagues demonstrated that postsynaptic expression of activated CaMKII in neuronal cultures leads to structural rearrangements that enhance connections from some presynaptic partners but eliminate connections from others (Pratt et al., 2003).

\section{Presynaptic role}

CaMKII also plays a role presynaptically. Measurements in the CA3-restricted null mutant indicate that presynaptic $\alpha$ CaMKII acts as an inhibitory constraint for neurotransmitter release, because these mice showed an enhancement of the activitydependent increase in the probability of release (Hinds et al., 2003). In addition, heterozygous and homozygous null mutants show a remarkable increase of the augmentation phase (first few seconds) of the posttetanic potentiation (Chapman et al., 1995) and a decrease in paired-pulse facilitation (PPF) (Silva et al., 1992a; Chapman et al., 1995). Surprisingly, although changes in PPF are considered to reflect presynaptic changes, PPF was normal in the CA3-restricted null mutant (Hinds et al., 2003). To what extent the presynaptic changes contribute to the cognitive phenotype of the mutants remains to be elucidated.

\section{Neocortical plasticity}

Similar to CA1-LTP, the induction of LTP in the visual cortex and barrel cortex of adult animals was shown to depend on $\alpha$ CaMKII and its autophosphorylation at $\mathrm{Thr}^{286}$ (Glazewski et al., 1996, 2000; Gordon et al., 1996; Kirkwood et al., 1997; Taha et al., 2002; Hardingham et al., 2003). Neocortical LTP, however, is more sensitive to the amount of $\alpha$ CaMKII than CA1-LTP, because heterozygous null mutants show normal CA1-LTP (Chapman et al., 1995; Frankland et al., 2001; Elgersma et al., 2002) but a remarkable reduction of LTP in the neocortex (Frankland et al., 2001).

Interestingly, adult but not adolescent (1-2 months old) $\alpha$ CaMKII null mutants are impaired in neocortical plasticity (Glazewski et al., 1996; Kirkwood et al., 1997). The lack of an impairment in the adolescent null mutants is thought to be caused by a compensation mechanism, which does not occur in the T286A mutants at this age (Glazewski et al., 2000). These findings may be analogous to the findings in the hippocampus as mentioned above, in which it was shown that a translocation of $\beta$ CaMKII can compensate for the loss of $\alpha$ CaMKII protein, but this compensation does not occur in the presence of mutated $\alpha$ CaMKII protein. Although autophosphorylation at $\mathrm{Thr}^{286}$ is essential for barrel cortex plasticity (Glazewski et al., 2000; Hardingham et al., 2003), overexpression of $\alpha$ CaMKII with the T286D mutation does not affect barrel cortex plasticity (Glazewski et al., 2001).

\section{$\alpha C a M K I I$ and cognition \\ Spatial learning}

$\alpha$ CaMKII mutants have been studied primarily in hippocampusdependent learning and memory tasks. Null mutants are severely impaired in spatial learning in the Morris water maze but show some learning after intensive training (Silva et al., 1992b; Elgersma et al., 2002). Similar to what has been found in the LTP studies, it is likely that a compensatory translocation of $\beta$ CaMKII to the postsynaptic density is responsible for this residual spatial learning (Elgersma et al., 2002). In the T305D and the T286A mutants, in which no $\beta$ CaMKII compensation occurs, a severe impairment was observed in spatial learning that cannot be rescued by overtraining (Giese et al., 1998; Elgersma et al., 2002). In principle, the spatial learning deficits could be caused by an interaction between the $\alpha$ CaMKII mutation and deprivation of the mice, which results from standard laboratory housing. However, environmental enrichment cannot rescue the spatial learning deficits in the T286A mutants (Need and Giese, 2003), indicating that the autophosphorylation of $\alpha$ CaMKII is essential for spatial learning.

Analysis of the T305/T306VA mutant has shown that inhibitory autophosphorylation is not strictly required for some spatial learning tasks but that phosphorylation of $\mathrm{Thr}^{305}$ is crucial for learning tasks that require flexible fine-tuning, such as reversal learning and contextual discrimination (Elgersma et al., 2002). For instance, T305/T306VA mutants can no longer find the platform in the water maze once it has been shifted to the opposite position in the pool, and they will show freezing in any chamber that has some similarity with the chamber in which the animals have been shocked.

Finally, analysis of the $3^{\prime}$ UTR deletion mutants revealed learning deficits in the Morris water maze. Moreover, these mutants show normal fear conditioning after $30 \mathrm{~min}$, whereas memory after $24 \mathrm{hr}$ is impaired (Miller et al., 2002). Such a phenotype is consistent with the observed role of $\alpha$ CaMKII in the protein synthesis-dependent phase of late LTP (Miller et al., 2002).

Not only mutations in the endogenous $\alpha$ CaMKII gene impair 
spatial learning, but also overexpression of $\alpha$ CaMKII affects learning in several hippocampus-dependent tasks, such as the Morris water maze, the Barnes maze, contextual conditioning, and novel object recognition (Bach et al., 1995; Mayford et al., 1996; Bejar et al., 2002; Wang et al., 2003). Because overexpression of $\alpha$ CaMKII $^{\mathrm{T} 286 \mathrm{D}}$ can be induced after the development of the brain has been completed, these studies demonstrate a direct role for $\alpha$ CaMKII in learning (Bach et al., 1995; Mayford et al., 1996; Bejar et al., 2002; Wang et al., 2003).

How do mutations in $\alpha$ CaMKII affect spatial learning? Place cells are hippocampal pyramidal neurons that fire when the animal is in a particular location, and they are thought to be essential for spatial learning (O'Keefe and Dostrovsky, 1971). Analysis of place cell activity in the T286A mutants showed that the autophosphorylation at $\mathrm{Thr}^{286}$ is needed for spatial selectivity (signalto-noise coding) and stability of place cells (Cho et al., 1998). Unstable place cells and impaired spatial learning in the Barnes maze were also found in the transgenic T286D mice expressing constitutive active $\alpha$ CaMKII (Bach et al., 1995; Rotenberg et al., 1996).

\section{Memory}

As mentioned above, plasticity of the neocortex seems more sensitive to reduced $\alpha$ CaMKII levels than hippocampal plasticity. This difference in sensitivity to $\alpha$ CaMKII levels probably underlies the remarkable phenotype of the heterozygous null mutants. These mutants are normal for recent memory after contextual conditioning or water maze training, but they are impaired in remote memory (>3 d after training) (Frankland et al., 2001). This finding was interesting because the hippocampus is thought to play only a temporary role in storage of contextual fear memory. Lesion studies have shown that the hippocampus is not required for contextual memory storage $28 \mathrm{~d}$ after training (Kim and Fanselow, 1992). Therefore, it has been suggested that contextual memory is transferred from the hippocampus to neocortex, and $\alpha$ CaMKII seems to contribute to this transfer. Consistent with this idea, the activation of immediate-early gene expression in neocortex is impaired in the $\alpha$ CaMKII heterozygotes after contextual fear conditioning (Frankland et al., 2004).

A direct role for $\alpha$ CaMKII in memory consolidation and/or retrieval was demonstrated using mice with an inducible T286D transgene. Activation of the transgene after learning resulted in impaired recall 6 weeks later (Mayford et al., 1996). The temporary contribution to memory consolidation could be tested more precisely using $\operatorname{Tg}(\mathrm{F} 89 \mathrm{G})$ mutants. The $\alpha \mathrm{CaMKII}^{\mathrm{F} 89 \mathrm{G}}$ contains an altered structural domain allowing specific and rapid (8 min after injection) blockade by a designed inhibitor in which the activity of the overexpressed $\alpha$ CaMKII ${ }^{\text {F89G }}$ can be downregulated. Increasing $\alpha$ CaMKII activity 1-7 d after training affected the recall test $30 \mathrm{~d}$ later, whereas no effects were observed when $\alpha$ CaMKII activity was changed between days 7 and 28 after training (Wang et al., 2003). This indicates that $\alpha$ CaMKII plays a critical role in memory consolidation during the first days after training. Furthermore, it was shown that $\alpha$ CaMKII is involved in memory recall, because the transgenic mice showed significantly less freezing in both contextual and cued freezing tested at either $1 \mathrm{~d}$ retention or 1 month retention when overexpressed $\alpha \mathrm{CaMKII}{ }^{\mathrm{F} 89 \mathrm{G}}$ was not inhibited at the time of testing (Wang et al., 2003).

\section{Other phenotypes}

Because $\alpha$ CaMKII is expressed in most brain areas, one could expect this kinase to be involved in all types of learning. However, normal learning was shown in several non-hippocampusdependent learning tasks, such as the visible platform water maze, plus maze, cued Barnes maze, olfactory discrimination, the acquisition of instrumental conditioning, and the accelerating rotarod (Silva et al., 1992b; Bach et al., 1995; Giese et al., 1998; Wiedenmayer et al., 2000; Carvalho et al., 2001; Elgersma et al., 2002).

Besides the almost surprising specificity of the learning impairments, a few other neurological phenotypes have been reported. Some of these behaviors (e.g., increased activity in an open field and Y-maze) parallel responses seen in hippocampuslesioned animals (Silva et al., 1992b). Also, the increased seizure susceptibility in some $\alpha$ CaMKII mutants (Butler et al., 1995; Elgersma et al., 2002) is likely to be associated with changes in hippocampal plasticity or could result from changes in intrinsic excitability. Another behavioral phenotype that has been observed is an abnormal fear response and concomitant increased aggression of the heterozygous null mutants (Chen et al., 1994), which severely complicates breeding of the animals. Because the phenotype has become progressively worse over the course of inbreeding and because it is not observed (yet?) in the recently developed knock-out strain (Elgersma et al., 2002), this phenotype is likely to be dependent on the genetic background of the animals. Abnormal fear responses may also explain deficits in the cued conditioning task. To our knowledge, this is up to now the only reported non-hippocampus-dependent learning task in which most of the $\alpha$ CaMKII mutants are shown to be impaired (Silva et al., 1992b, 1996; Bach et al., 1995; Mayford et al., 1996; Bejar et al., 2002; Miller et al., 2002; Wang et al., 2003).

\section{Human learning and memory}

To date, no mutations have been identified in the human $\alpha$ CaMKII gene that could underlie a genetic neurological disease. However, recent findings suggest that abnormal $\alpha$ CaMKII activity is likely to contribute to the symptoms of AS. AS is a form of mental retardation associated with profound cognitive dysfunction, including severe learning deficits and an associated ataxia (Clayton-Smith and Laan, 2003; Guerrini et al., 2003). The human AS gene encodes an ubiquitin ligase: specifically the UBE3A (i.e., E6-AP) ubiquitin ligase that transfers ubiquitin moieties to a restricted set of substrate proteins (Matsuura et al., 1997; Clayton-Smith and Laan, 2003; Guerrini et al., 2003). This information was used by two groups to independently generate two mouse models of AS (Jiang et al., 1998; Miura et al., 2002). Using these mouse models, both groups found that the Ube3a gene is imprinted with silencing of the paternal allele in hippocampus and cerebellum in mice, as it is in humans (Albrecht et al., 1997). In other words, the product of the maternal Ube3a gene is selectively absent in the hippocampus, olfactory bulb, and cerebellum in human AS and in the mouse AS model. The behavioral phenotype of mice with maternal deficiency $\left(\mathrm{m}^{-} / \mathrm{p}^{+}\right)$for Ube3a resembles human Angelman's syndrome, manifesting motor dysfunction, inducible seizures, and a context-dependent associative learning deficit (Jiang et al., 1998; Miura et al., 2002). CA1-LTP is also severely impaired in $\mathrm{m}^{-} / \mathrm{p}^{+}$mice, despite normal baseline synaptic transmission and neuroanatomy, indicating that ubiquitination plays a role in regulating mammalian LTP (Jiang et al., 1998; Weeber et al., 2003). Physiological studies of synaptic plasticity in the AS model mouse hippocampal slices in vitro indicate that the AS-associated defects in the mouse model appear to be downstream of postsynaptic calcium influx, implicating known targets of calcium signaling as potential mediators of dysfunction (Weeber et al., 2003). Significantly, AS model mutant animals exhibit a significant increase in hippocampal phospho-CaMKII, specifically at sites $\mathrm{Thr}^{286}$ and $\mathrm{Thr}^{305}$, with no corresponding change in the levels of total CaMKII. In addition, 
these mutants show reduced CaMKII enzymatic activity and decreased post hoc autophosphorylation capability (Weeber et al., 2003). Interestingly, despite its increased phosphorylation at $\mathrm{Thr}^{286}$, there is less CaMKII associated with the postsynaptic density, providing additional evidence that phosphorylation at $\mathrm{Thr}^{305}$ reduces the affinity for the postsynaptic density (Elgersma et al., 2002; Weeber et al., 2003). Because this phenotype shows a remarkable similarity with the CaMKII mutants mimicking persistent Thr $^{305}$ phosphorylation (Elgersma et al., 2002), these findings suggest that misregulation of CaMKII phosphorylation may account for many of the synaptic plasticity deficits and behavioral deficits in the mouse model for AS (Weeber et al., 2003). The misregulation of CaMKII dephosphorylation is probably caused by the decreased protein phosphatase PP1/PP2A activity in this mutant based on in vitro studies of phosphatase activity in the AS model mice (Weeber et al., 2003). Although both phosphatases have been directly implicated in CaMKII regulation (Colbran, 2004), the linkage between the UBE3A gene product and regulation of phosphatase activity is completely mysterious at this point.

\section{Conclusion}

Mouse genetic approaches have provided us with a wealth of information on the role of $\alpha$ CaMKII in plasticity and cognition. These studies would not have been possible without the overwhelming amount of data gathered from biochemical and cellular studies over the last two decades. Conversely, without the mutants, the physiological relevance of these in vitro findings could not have been revealed. $\alpha$ CaMKII mutants have also proven to be a useful tool to unravel the temporal aspects of memory acquisition, consolidation, and retrieval. Studies on $\alpha$ CaMKII mutants have been one of the leading areas in investigating the molecular basis of synaptic plasticity historically, and there are exciting times ahead as investigations in this area continue.

\section{References}

Abraham WC, Tate WP (1997) Metaplasticity: a new vista across the field of synaptic plasticity. Prog Neurobiol 52:303-323.

Albrecht U, Sutcliffe JS, Cattanach BM, Beechey CV, Armstrong D, Eichele G, Beaudet AL (1997) Imprinted expression of the murine Angelman syndrome gene, Ube3a, in hippocampal and Purkinje neurons. Nat Genet 17:75-78.

Bach ME, Hawkins RD, Osman M, Kandel ER, Mayford M (1995) Impairment of spatial but not contextual memory in CaMKII mutant mice with a selective loss of hippocampal LTP in the range of the theta frequency. Cell 81:905-915.

Bejar R, Yasuda R, Krugers H, Hood K, Mayford M (2002) Transgenic calmodulin-dependent protein kinase II activation: dose-dependent effects on synaptic plasticity, learning, and memory. J Neurosci 22:5719-5726.

Brocke L, Chiang LW, Wagner PD, Schulman H (1999) Functional implications of the subunit composition of neuronal CaM kinase II. J Biol Chem 274:22713-22722.

Butler LS, Silva AJ, Abeliovich A, Watanabe Y, Tonegawa S, McNamara JO (1995) Limbic epilepsy in transgenic mice carrying a $\mathrm{Ca}^{2+} /$ calmodulindependent kinase II alpha-subunit mutation. Proc Natl Acad Sci USA 92:6852-6855.

Carvalho OM, Silva AJ, Balleine BW (2001) Evidence of selective learning deficits on tests of Pavlovian and instrumental conditioning in $\alpha$-CaMKII ${ }^{\text {T286A }}$ mutant mice. Int J Comp Psych 14:161-174.

Chapman PF, Frenguelli BG, Smith A, Chen CM, Silva AJ (1995) The alpha$\mathrm{Ca}^{2+} /$ calmodulin kinase II: a bidirectional modulator of presynaptic plasticity. Neuron 14:591-597.

Chen C, Rainnie DG, Greene RW, Tonegawa S (1994) Abnormal fear response and aggressive behavior in mutant mice deficient for alphacalcium-calmodulin kinase II. Science 266:291-294.

Cho YH, Giese KP, Tanila H, Silva AJ, Eichenbaum H (1998) Abnormal hippocampal spatial representations in $\alpha \mathrm{CaMKII}^{\mathrm{T} 286 \mathrm{~A}}$ and $\mathrm{CREB}^{\alpha \Delta}$ mice. Science 279:867-869.

Clayton-Smith J, Laan L (2003) Angelman syndrome: a review of the clinical and genetic aspects. J Med Genet 40:87-95.

Colbran RJ (2004) Protein phosphatases and calcium/calmodulindependent protein kinase II-dependent synaptic plasticity. J Neurosci 24:8404-8409.

Elgersma Y, Fedorov NB, Ikonen S, Choi ES, Elgersma M, Carvalho OM, Giese KP, Silva AJ (2002) Inhibitory autophosphorylation of CaMKII controls PSD association, plasticity, and learning. Neuron 36:493-505.

Frankland PW, O'Brien C, Ohno M, Kirkwood A, Silva AJ (2001) AlphaCaMKII-dependent plasticity in the cortex is required for permanent memory. Nature 411:309-313.

Frankland PW, Bontempi B, Talton LE, Kaczmarek L, Silva AJ (2004) The involvement of the anterior cingulate cortex in remote contextual fear memory. Science 304:881-883.

Giese KP, Fedorov NB, Filipkowski RK, Silva AJ (1998) Autophosphorylation at Thr286 of the $\alpha$ calcium-calmodulin kinase II in LTP and learning. Science 279:870-873.

Glazewski S, Chen CM, Silva A, Fox K (1996) Requirement for alphaCaMKII in experience-dependent plasticity of the barrel cortex. Science 272:421-423.

Glazewski S, Giese KP, Silva A, Fox K (2000) The role of alpha-CaMKII autophosphorylation in neocortical experience-dependent plasticity. Nat Neurosci 3:911-918.

Glazewski S, Bejar R, Mayford M, Fox K (2001) The effect of autonomous alpha-CaMKII expression on sensory responses and experiencedependent plasticity in mouse barrel cortex. Neuropharmacology 41:771-778.

Gordon JA, Cioffi D, Silva AJ, Stryker MP (1996) Deficient plasticity in the primary visual cortex of alpha-calcium/calmodulin-dependent protein kinase II mutant mice. Neuron 17:491-499.

Guerrini R, Carrozzo R, Rinaldi R, Bonanni P (2003) Angelman syndrome: etiology, clinical features, diagnosis, and management of symptoms. Paediatr Drugs 5:647-661.

Hardingham N, Glazewski S, Pakhotin P, Mizuno K, Chapman PF, Giese KP, Fox K (2003) Neocortical long-term potentiation and experiencedependent synaptic plasticity require $\alpha$-calcium/calmodulin-dependent protein kinase II autophosphorylation. J Neurosci 23:4428-4436.

Hinds HL, Tonegawa S, Malinow R (1998) CA1 long-term potentiation is diminished but present in hippocampal slices from alpha-CaMKII mutant mice. Learn Mem 5:344-354.

Hinds HL, Goussakov I, Nakazawa K, Tonegawa S, Bolshakov VY (2003) Essential function of alpha-calcium/calmodulin-dependent protein kinase II in neurotransmitter release at a glutamatergic central synapse. Proc Natl Acad Sci USA 100:4275-4280.

Jiang YH, Armstrong D, Albrecht U, Atkins CM, Noebels JL, Eichele G, Sweatt JD, Beaudet AL (1998) Mutation of the Angelman ubiquitin ligase in mice causes increased cytoplasmic p53 and deficits of contextual learning and long-term potentiation. Neuron 21:799-811.

Kim JJ, Fanselow MS (1992) Modality-specific retrograde amnesia of fear. Science 256:675-677.

Kirkwood A, Silva A, Bear MF (1997) Age-dependent decrease of synaptic plasticity in the neocortex of alphaCaMKII mutant mice. Proc Natl Acad Sci USA 94:3380-3383.

Matsuura T, Sutcliffe JS, Fang P, Galjaard RJ, Jiang YH, Benton CS, Rommens JM, Beaudet AL (1997) De novo truncating mutations in E6-AP ubiquitin-protein ligase gene (UBE3A) in Angelman syndrome. Nat Genet 15:74-77.

Mayford M, Wang J, Kandel ER, O’Dell TJ (1995) CaMKII regulates the frequency-response function of hippocampal synapses for the production of both LTD and LTP. Cell 81:891-904.

Mayford M, Bach ME, Huang YY, Wang L, Hawkins RD, Kandel ER (1996) Control of memory formation through regulated expression of a CaMKII transgene. Science 274:1678-1683.

Miller S, Yasuda M, Coats JK, Jones Y, Martone ME, Mayford M (2002) Disruption of dendritic translation of CaMKIIalpha impairs stabilization of synaptic plasticity and memory consolidation. Neuron 36:507-519.

Miura K, Kishino T, Li E, Webber H, Dikkes P, Holmes GL, Wagstaff J (2002) Neurobehavioral and electroencephalographic abnormalities in Ube3a maternal-deficient mice. Neurobiol Dis 9:149-159.

Need AC, Giese KP (2003) Handling and environmental enrichment do not 
rescue learning and memory impairments in alphaCamKII(T286A) mutant mice. Genes Brain Behav 2:132-139.

O’Keefe J, Dostrovsky J (1971) The hippocampus as a spatial map. Preliminary evidence from unit activity in the freely-moving rat. Brain Res 34:171-175.

Park D, Coleman MJ, Hodge JJ, Budnik V, Griffith LC (2002) Regulation of neuronal excitability in Drosophila by constitutively active CaMKII. J Neurobiol 52:24-42.

Pratt KG, Watt AJ, Griffith LC, Nelson SB, Turrigiano GG (2003) Activitydependent remodeling of presynaptic inputs by postsynaptic expression of activated CaMKII. Neuron 39:269-281.

Rotenberg A, Mayford M, Hawkins RD, Kandel ER, Muller RU (1996) Mice expressing activated CaMKII lack low frequency LTP and do not form stable place cells in the CAl region of the hippocampus. Cell 87:1351-1361.

Silva AJ, Stevens CF, Tonegawa S, Wang Y (1992a) Deficient hippocampal long-term potentiation in alpha-calcium- calmodulin kinase II mutant mice. Science 257:201-206.

Silva AJ, Paylor R, Wehner JM, Tonegawa S (1992b) Impaired spatial learning in alpha-calcium-calmodulin kinase II mutant mice. Science 257:206-211.

Silva AJ, Rosahl TW, Chapman PF, Marowitz Z, Friedman E, Frankland PW, Cestari V, Cioffi D, Sudhof TC, Bourtchuladze R (1996) Impaired learning in mice with abnormal short-lived plasticity. Curr Biol 6:1509-1518.

Taha S, Hanover JL, Silva AJ, Stryker MP (2002) Autophosphorylation of
alphaCaMKII is required for ocular dominance plasticity. Neuron 36:483-491.

Varga AW, Yuan LL, Anderson AE, Schrader LA, Wu GY, Gatchel JR, Johnston D, Sweatt JD (2004) Calcium-calmodulin-dependent kinase II modulates Kv4.2 channel expression and upregulates neuronal A-type potassium currents. J Neurosci 24:3643-3654.

Wang H, Shimizu E, Tang YP, Cho M, Kyin M, Zuo W, Robinson DA, Alaimo PJ, Zhang C, Morimoto H, Zhuo M, Feng R, Shokat KM, Tsien JZ (2003) Inducible protein knockout reveals temporal requirement of CaMKII reactivation for memory consolidation in the brain. Proc Natl Acad Sci USA 100:4287-4292.

Weeber EJ, Jiang YH, Elgersma Y, Varga AW, Carrasquillo Y, Brown SE, Christian JM, Mirnikjoo B, Silva A, Beaudet AL, Sweatt JD (2003) Derangements of hippocampal calcium/calmodulin-dependent protein kinase II in a mouse model for Angelman mental retardation syndrome. J Neurosci 23:2634-2644.

Wiedenmayer CP, Myers MM, Mayford M, Barr GA (2000) Olfactory based spatial learning in neonatal mice and its dependence on CaMKII. NeuroReport 11:1051-1055.

Yasuda H, Barth AL, Stellwagen D, Malenka RC (2003) A developmental switch in the signaling cascades for LTP induction. Nat Neurosci 6: $15-16$. 